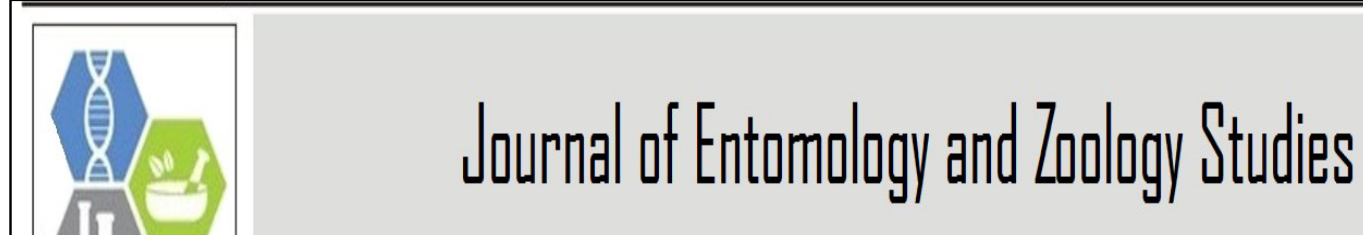

Available online at www.entomoljournal.com

E-ISSN: 2320-7078

P-ISSN: 2349-6800

JEZS 2016; 4(6): 483-484

(C) $2016 \mathrm{JEZS}$

Received: 03-09-2016

Accepted: 04-10-2016

Mark Ian Cooper

Department of Biological

Sciences, University of Cape

Town, Private Bag, Rondebosch

7701, Republic of South Africa
Correspondence

Mark Ian Cooper

Department of Biological

Sciences, University of Cape

Town, Private Bag, Rondebosch

7701, Republic of South Africa

\section{Syncopulatory mate-guarding affected by predation in the aposematic millipede Centrobolus inscriptus in a swamp forest}

\section{Mark Ian Cooper}

\section{Abstract}

Mate-guarding can be affected by predation. While filming mate-guarding and prolonged copulations in a South African swamp forest aposematic millipede observations were made of the results of predation on a mated pair. This is a documentation of the sheared male coleopods inserted remains in the female forest millipede Centrobolus inscriptus and incidentally corroborates the lock-and-key hypothesis for the evolution of millipede genitalia (gonopods (coleopods)).

Keywords: Genitalia, lock-and-key hypothesis, millipede, predation

\section{Introduction}

Mate-guarding is known to affect predation risk ${ }^{[1]}$. Predation on millipedes includes attacks from both vertebrates and invertebrates ${ }^{[2]}$. Specialist millipede predators include dung beetles ${ }^{[3]}$ and assassin bugs ${ }^{[4]}$. Some predator species are generalists ${ }^{[5]}$. Millipedes have evolved both physical and chemical weapons to prevent predation ${ }^{[6-7]}$. In combination some species use a warning and glowing colours to deter predators from the distasteful prey ${ }^{[8,9]}$. The genus Centrobolus contains 39 completely aposematic species ${ }^{[10]}$. C. inscriptus (Attems 1928) is an aposematically coloured mate-guarding millipede with prolonged copulations ${ }^{[11-27]}$.

Here I document the potential affect of predatory attacks on mate-guarding and incidentally corroborate the lock-and-key hypothesis for the evolution of millipede genitalia in the forest species $C$. inscriptus by witnessing the remains of a mated pair which was exposed to natural predation.

\section{Materials and methods}

Forest millipedes were observed, photographed and filmed in situ at Mtunzini Chalets, a. k. a. Mtunzini Forest Lodge (28 57'59.70’S, 3145’08.29’E), during the 2004/2005 wet season. Mating pairs were examined in the presence of predation. Female millipedes were observed to see an extreme effect of predation on mate-guarding millipedes.

\section{Results}

The filmed material formed the opening series of Life in the Undergrowth: Invasion of the Land and is available online at http://www.bbc.co.uk/programmes/b0074s26. Observations were made of a mated female after an unknown predatory attack on a mating pair. The author clearly viewed the detached male gonopod pairs inserted into a female Centrobolus inscriptus.

\section{Discussion}

Here I corroborate the lock-and-key hypothesis - the original hypothesis for the evolution of male and female genitalia ${ }^{[28-30]}$ - by witnessing the effects of a predatory attack on an aposematic millipede mating pair. The observation of predation on $C$. inscriptus may support a future test of the "hypothesis that a warning colouration pattern involving yellow spots symmetrically distributed along the millipede body can mediate [avian] predator avoidance $[8], "$

\section{Conclusion}

Mate-guarding is affected by predation in the millipede Centrobolus inscriptus. 


\section{Acknowledgements}

Thanks to the British Broadcasting Corporation Natural History Unit and the Wildlife and Environment Society of Southern Africa who facilitated this research.

\section{References}

1. Cothran RD. Precopulatory mate guarding affects predation risk in two freshwater amphipod species. Animal Behaviour. 2004; 68(5):1133-1138.

2. Peeters C, DeGreef S. Predation on large millipedes and self-assembling chains in Leptogenys ants from Cambodia. Insectes Sociaux. 2015; 62:471-477.

3. Larsen TH, Lopera A, Forsyth A, Génier F. From coprophagy to predation: a dung beetle that kills millipedes. Biology Letters. 2009; 5:152-155.

4. Forthman M, Weirouch C. Toxic associations: A review of the predatory behaviors of millipede assassin bugs (Hemiptera: Reduviidae: Ectrichodiinae). European Journal of Entomology. 2012; 109(2):147-153.

5. Brunke AJ, Bahlai CA, Sears MK, Hallett RH. Generalist Predators (Coleoptera: Carabidae, Staphylinidae) Associated with Millipede Populations in Sweet Potato and Carrot Fields and Implications for Millipede Management. Environmental Entomology. 2009; 38(4):1106-1116.

6. Tuf IH, Čmielová L, Šipoš J. Conglobation as a defensive behaviour of pill millipedes (Diplopoda: Glomerida). Acta Societatis Zoologicae Bohemicae. 2016; 80:39-44.

7. Shear WA. The chemical defenses of millipedes (diplopoda): biochemistry, physiology and ecology. Biochemical Systematics and Ecology. 2015; 61:78-117.

8. Marek P, Papaj D, Yeager J, Molina S, Moore W. Bioluminescent aposematism in millipedes. Current Biology. 2011; 21(18):R680-R681.

9. Iniesta LFM, Ratton P, Guerra TJ. Avian predators avoid attacking artificial aposematic millipedes in Brazilian Atlantic Forest. Journal of Tropical Ecology. 2016; 1-5.

10. Hamer M. Checklist of Southern African millipedes (Myriapoda: Diplopoda). Annals of the Natal Museum. 1998; 39:11-82.

11. Cooper MI, Telford SR. Copulatory Sequences and Sexual Struggles in Millipedes. Journal of Insect Behaviour. 2000; 13(2):217-230.

12. Cooper MI. Sex ratios, mating frequencies and relative abundance of sympatric millipedes in the genus Chersastus (Diplopoda, Pachybolidae). Arthropods. 2014; 3(4):174-176.

13. Cooper MI. Sexual size dimorphism and corroboration of Rensch's rule in Chersastus millipedes (Diplopoda, Pachybolidae). Journal of Entomology and Zoology Studies. 2014; 2(6):264-26.

14. Cooper MI. Competition affected by re-mating interval in a myriapod. Journal of Entomology and Zoology Studies. 2015; 3(4):77-78.

15. Cooper MI. Elaborate gonopods in the myriapod genus Chersastus (Diplopoda, Trigoniulidae). Journal of Entomology and Zoology Studies. 2015; 3(4):235-238.

16. Cooper MI. Sperm storage in Centrobolus spp. and observational evidence for egg simulation. Journal of Entomology and Zoology Studies. 2016; 4(1):127-129.

17. Cooper MI. Fire millipedes obey the female sooner norm in cross mating Centrobolus (Myriapoda). Journal of Entomology and Zoology Studies. 2016; 4(1):173-174.

18. Cooper MI. Symmetry in ejaculate volumes of
Centrobolus inscriptus Attems (Spiroboloidea, Trigoniulidae). Journal of Entomology and Zoology Studies. 2016; 4(1):386-387.

19. Cooper MI. Instantaneous insemination in the millipede Centrobolus inscriptus (Spirobolida, Trigoniulidae) determined by artificially-terminated mating. Journal of Entomology and Zoology Studies. 2016; 4(1):487-490.

20. Cooper MI. Gonopod mechanics in Centrobolus Cook (Spirobolida, Trigoniulidae) II. Images. Journal of Entomology and Zoology Studies. 2016; 4(2):152-154.

21. Cooper MI. Post-insemination associations between males and females in Diplopoda: A remark on Alcock's (1994) predictions of the mate-guarding hypothesis. Journal of Entomology and Zoology Studies. 2016; 4(2):283-285.

22. Cooper MI. Heavier-shorter-wider females in the millipede Centrobolus inscriptus Attems (Spirobolida, Trigoniulidae). Journal of Entomology and Zoology Studies. 2016; 4(2):509-510.

23. Cooper MI. Sexual bimaturism in the millipede Centrobolus inscriptus Attems (Spirobolida, Trigoniulidae). Journal of Entomology and Zoology Studies. 2016; 4(3):86-87.

24. Cooper MI. Tarsal pads of Centrobolus Cook (Spiroboloidea, Trigoniulidae). Journal of Entomology and Zoology Studies. 2016; 4(3):385-386.

25. Cooper MI. Confirmation of four species of Centrobolus Cook (Spirobolida: Trigoniulidae) based on gonopod ultrastructure. Journal of Entomology and Zoology Studies. 2016; 4(4):389-391.

26. Cooper MI. Sperm storage in Centrobolus inscriptus Attems (Spirobolida: Trigoniulidae). Journal of Entomology and Zoology Studies. 2016; 4(4):392-393.

27. Cooper MI. Sperm dumping in Centrobolus inscriptus Attems (Spirobolida: Trigoniulidae). Journal of Entomology and Zoology Studies. 2016; 4(4):394-395.

28. Arnqvist G. The evolution of animal genitalia: distinguishing between hypotheses by single species studies. Biological Journal of the Linnean Society 1997; $60(3): 365-379$.

29. Masly JP. 170 Years of Lock-and-Key: Genital Morphology and Reproductive Isolation. International Journal of Evolutionary Biology Article. ID 247352: 2012, 10.

30. Shapiro AM, Porter AH. The Lock-and-Key Hypothesis: Evolutionary and Biosystematic Interpretation of Insect Genitalia. Annual Review of Entomology. 1989; 34:231245 . 